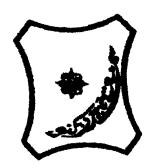

Bayero Journal of Pure and Applied Sciences, 14(1): 85 - 94

Received: January, 2021

Accepted: March, 2021

ISSN 2006 - 6996

\title{
PHYTOCHEMICAL CONSTITUENTS AND ANTIBACTERIAL ACTIVITIES OF INDIGENOUS CHEWING STICK (Anogeissus leiocarpus) Stem
}

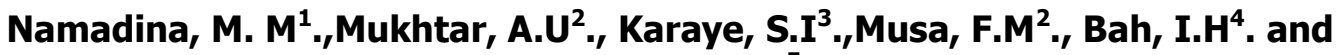 \\ Maitama, F.Y. ${ }^{5}$ \\ ${ }^{1}$ Department of Plant Biology, Bayero University, Kano, Nigeria. \\ ${ }^{2}$ Department of Microbiology, Kaduna State University. \\ ${ }^{3}$ Department of Forestry, Audu Bako Collage of Agriculture, Danbatta \\ ${ }^{4}$ Department of Integrated Science, Federal College of Education, Kano \\ ${ }^{5}$ Department of Biological Sciences, Bayero University, Kano \\ Corresponding Author: Hajiyaiyalle@gmail.commnmuhammad.bot@buk.edu.ng 07035939668
}

\section{ABSTRACT}

The stems from Anogeissus leiocarpus are commonly used as chewing sticks in Northern Nigeria. If properly used, the chewing sticks have proven to be effective in removing dental plaque due to mechanical cleaning and enhanced salivation. Chewing sticks from other plants have been shown to display antimicrobial activities against a broad spectrum of microorganisms. However, there is limited information available in Northern Nigeria on the chemical composition, antimicrobial properties and the ability of the plants under study to prevent bacterial adhesion to tooth surface. Therefore, the purpose of this study was to ascertain the phytochemical and antibacterial properties of Anogeissus leiocarpus and correlate the results obtained to their ethnomedicinal uses as chewing sticks. Powdered stem was exhaustively extracted using methanol at room temperature for 72 hours. Antibacterial activities of the methanol extract was assessed using the agar well diffusion methods against the oral pathogens, Staphylococcus aureus, Streptococcus salivarius, Streptococcus pyogenes, Streptococcus mutansand Streptococcus sanguinis. Acute toxicity study was achieved using Lorke method. Phytochemicals which include flavonoid, steroid, triterpenes, alkaloids, tannins, carbohydrate, glycoside, phenols were detected in the extracts while anthraquinones was absent. The antibacterial results revealed that, the methanol extract had promising antibacterial activity. S. aureuswas found to be the most susceptible bacteria at $500 \mathrm{mg} / \mathrm{ml}$ with inhibition of $22 \mathrm{~mm}$, Streptococcus salivarius, Streptococcus pyogenes and Streptococcus sanguinis were inhibited at $16 \mathrm{~mm}$ while Streptococcus mutans showed inhibition of $14 \mathrm{~mm}$. The extract have MIC and MBC of $31.25 \mathrm{mg} / \mathrm{ml}$ and $62.5 \mathrm{mg} / \mathrm{ml}$ respectively against all the tested clinical isolates. The $L D_{50}$ of Anogeissus leiocarpus was found to be greater than $5000 \mathrm{mg}$ $/ \mathrm{kg}$ and could be considered safe for consumption.

Keywords: Anogeissus leiocarpus, Phytochemical, Toxicity, Antibacterial activity

\section{INTRODUCTION}

Different methods of oral hygiene are used in different countries and cultures. In Africa, the two preferred methods used are the toothbrushtoothpaste and the use of chewing sticks which are used by both adults and children (Moola, 2014). The common plants from which chewing sticks are sourced in Northern Nigeria are Anogeissusleiocarpus, Azadirachtaindica, Albiziachevalieri, Pseudocedrelakotschyi and Diospyrossp.. The choice between these methods is influenced by personal preferences, perceived effectiveness, availability and the medicinal properties (Aderinokun et al., 1999), whereas agreeable taste and anti-plaque activity are also considered by many. A study by Odongo et al. (2011) revealed that the choice of plants used as sources of chewing stick is mainly driven by the high fiber content of their stems and branches. Chewing stick users mention various reasons for choosing a stick over the toothbrush and toothpaste method. Among the reasons includes; ease of access (proximity), availability, reliability, efficiency, no cost and age long practice (Odongo et al., 2011). Moreover, the use of chewing sticks has been recommended by the World Health Organization (WHO) as an effective tool for oral hygiene (Cai et al., 2000). The sticks can be used fresh or may be dried and kept for later use. 
BAJOPAS Volume 14 Number 1, June, 2021

To prepare a stick, the plant part is cut into a suitable size, cleaned and the bark removed on the side to be used for cleaning (Moola, 2014). When the stick is chewed, the fibers at the end become loose, forming a rough "brush" which cleans the teeth surface. Continued chewing on the stick dislodges particles between the teeth and stimulates blood circulation in the gums (Moola, 2014). Chewing also increases saliva production; the later acts as a natural mouthwash that rinses away bacteria and creates an inhospitable environment for them to flourish (Hoque et al., 2007).

Oral health is fundamental to the general wellbeing and relates to the quality of life that affects the functions of the oral cavity, dental and soft tissues of the face (Moola, 2014). Millions of people around the world are affected by diseases and conditions of the oral cavity. These effects include pain, bad breath, and difficulty in speaking, chewing and swallowing and in some cases death can result (Moola, 2014). Pathogens causing oral diseases are evolving at a faster rate and most have developed resistance to drugs used clinically. Because of this, oral diseases continue to be a major health problem worldwide (Moola, 2014). Dental caries and periodontal diseases are among the most important global oral health problems. Although gum disease is the most common cause of tooth loss in adults, the early signs and symptoms which include bleeding gums and loose teeth are often seen by many as part of the aging process (Moola, 2014). Naturally, humans are a host of a variety of microorganisms. Over 750 species of bacteria are found in the oral cavity alone and many of these play a role in causing oral diseases. While some of these microorganisms are harmful, others help in preventing diseases by fighting diseases causing germs in the mouth. There is a link between oral diseases and the activities of microbial species that form part of the microbiota of the oral cavity. Among other microorganisms involved in the development of dental caries are Streptococcus mutans, $S$. sanguinis, S. sobrinus and Lactobacilli (Palombo, 2009). Periodontal diseases have mainly been associated with Actinomyces, Actinobacillus, Streptococcus and Candida species (More et al., 2008). The $S$. mutans strains make up at least $90 \%$ of what affects the oral cavity negatively (Moola, 2014), and it is also known to cause pneumonia, sinusitis, and meningitis. S. mutans and $S$. sanguinis are members of the human indigenous biota belonging to the genus Streptococcus of spherical Gram-positive bacteria (Moola, 2014). They form part of the bacterial community in plaque which is the main cause of dental disease. On average, Streptococci bacteria account for less than $10 \%$ of bacteria species in the plaque, indicating that other bacterial species play a role in caries formation (Moola, 2014). Streptococcus and other bacterial species metabolize sugar in the mouth to produce organic acids, mainly lactic acid that dissolves the calcium phosphate in teeth which leads to tooth decay (More et al. 2008; Palombo, 2009; Moola, 2014).

Anogeissusleiocarpus (DC.) Gill \& Peer is adeciduous tree species that can grow up to 15 $18 \mathrm{~m}$ of height and measure up to $1 \mathrm{~m}$ diameter (Ahmad, 2014). Bark greyish and scaly, branches often drooping and slender, leaves alternate, ovate lanceolate in shape, 2 - $8 \mathrm{~cm}$ long and 1.3 - $5 \mathrm{~cm}$ across (Ouedraogo et al., 2013). The leaves are acute at the apex and attenuate at the base, pubescent beneath. Inflorescence globose heads, $2 \mathrm{~cm}$ across, yellow; the flowers are bisexual, petals absent. Fruits are globose, cone like heads; each fruit is broadly winged, dark grey, $3 \mathrm{~cm}$ across. It can reproduce by seeds as well as vegetative propagation (Mukhtar et al., 2017). The plant is popularly known as African birch, Axle wood tree (Victor et al., 2013); "Marke", "Faringamji" in Hausa, "Kojoli" in Fulfulde, "Kukunchi" in Nupe, "Annum" in Kanuri, "Ainy" or "Orin-odon" in Yoruba and "Atara" in Igbo language of Nigeria (Victor et al., 2013). The plant has been reported to used traditionally for the treatment of different ailments including the treatment of diabetes, ulcers, general body pain, blood clots, asthma, coughing, jaundice, pile and tuberculosis (Abubakar et al., 2017), Malaria, Trypansomiasis, Helminthiasis and dysenteric syndrome (Okpekon, 2004) and also, it is used against stomach infections and fungal infections such as dermatitis and Mycosis (Batawila et al., 2005). Recent studies have revealed that the plant exhibits a variety of pharmacological activities including Antiplasmodial (Akanbi, 2012), Antioxidant and hepatoprotective (Victor and Grace, 2013) Leishmanicidal (Shuaibu, 2008a) Anthelmintic (Agaie and Onyeyili, 2007; Ademola and Eloff, 2011) Trypanocidal (Shuaibu, 2008b) antimicrobial (Taiwo et al., 1999; Elegami, 2002).

The objective of the present investigation is to establish some important antibacterial profile and safety margin of $A$. leiocarpus stem with the hope of assisting in its standardization and safety. 
BAJOPAS Volume 14 Number 1, June, 2021

MATERIALS AND METHODS

\section{Ethical Approval}

Ethical clearance with the number $\mathrm{MOH} / \mathrm{Off} / 797 / \mathrm{T} . \mathrm{I} / 645$ was obtained from the ethical committee of Kano State Hospital Management Board, Kano State Ministry of Health for all the sample collection.

Collection of Clinical Specimen

The consent of patients that presented tooth infections cases were sought before taking their samples (oral cavity). Ten (10) consecutive, non-duplicate samples were collected at the General out Patient (GOP) clinic of the Bayero University Kano in the morning hours.

Plaque samples from their oral cavity were collected in sterile tubes containing $2 \mathrm{ml}$ normal saline using swap stick. Samples were stored in an ice box then transported to the laboratory for processing at Microbiology Laboratory, Bayero University Kano, Kano State, Nigeria. .

\section{Isolation of Bacteria Species}

The specimens were cultured on sterile blood agar, chocolate agar and mac-conkey agar plates at $37^{\circ} \mathrm{C}$ for $24 \mathrm{~h}$ in an incubator. Discrete colonies were picked based on their morphology and further sub-cultured on blood agar and chocolate agar to obtain pure strains. The isolated colonies were gram stained and based on their gram reactions were inoculated on different selective media; mannitol salt agar, cetrimide agar, eosin methylene blue agar. Different biochemical tests were conducted (catalase test, coagulase test, oxidase test. All the isolates that grew on selected agar media were then placed on nutrient agar and chocolate agar slants and maintained in a refrigerator at $4^{\circ} \mathrm{C}$ (Cheesbrough, 2010).

Identification and Characterization of Test Organism using Rapid Test Kits

Identification and characterization of the bacteria was carried out using Microgen Identification Kit (XYZ).The test was performed according to the manufacturer's specifications (API biomerieux). It was performed by adding saline suspension of the test organisms to each of the wells and appropriate wells (1, 2, 3 and 9) were overlaid with sterile paraffin oil. After overnight incubation (18-24 hours) at $37^{\circ} \mathrm{C}$, suitable reagents (such as Nitrate $A$ and $B$, Kovacs, Typtophan deaminase (TDA), Vogesproskauer (VPI and II) were added to wells 8, 10 and 12 for additional tests and colour changes of the different tests recorded. The results were converted into four to eight digits codes depending on the organisms being tested and interpreted using the Microgen Identification Software Package (MID-60) (Sylvester, 2016).

Collection and Identification of Plant Materials

The stems of Anogeissusleiocarpus were collected from local farm in March, 2017 at Babura Local Government Area, Jigawa State, Nigeria. The plant was identified and authenticated in the herbarium of the Plant Biology Department of Bayero University, Kano, Kano State, Nigeria and a voucher specimen number (BUKHAN29) was deposited.

\section{Preparation of Plant extracts}

The stem of the plant was cleaned, air dried and ground to coarse powder using grinding machine. The powder was stored in air tight containers for further use. Fifty grams $(50 \mathrm{~g})$ of the powdered stem was soaked into $500 \mathrm{ml}$ of methanol. The mixtures were allowed to stand for 3 days at room temperature $\left(28 \pm 2^{\circ} \mathrm{C}\right)$ with hourly agitations. The extract was sieved through a muslin cloth, filtered through a Whatman (No.1) filter paper, poured unto a clean evaporating dish and placed on a water bath at $50^{\circ} \mathrm{C}$ until all the solvent evaporated.

Qualitative Phytochemical screening of Methanolic extract of Anogeissus leiocarpus Stem

The plant extract was subjected to phytochemical screening in order to identify the phytochemical constituents of the plant.

Tests for carbohydrates

Molish's (General) Test for Carbohydrates:

To $1 \mathrm{ml}$ of the filtrate, $1 \mathrm{ml}$ of Molish's reagent was added in a test tube, followed by $1 \mathrm{ml}$ of concentrated sulphuric acid down the test tube to form a lower layer. A reddish colour at the interfacial ring indicates the presence of carbohydrate (Evans, 2009).

\section{Tests for Saponins}

Frothing test: About $10 \mathrm{ml}$ of distilled water was added to a portion of the extract and was shaken vigorously for 30 seconds. The tube was allowed to stand in a vertical position and was observed for 30 mins. A honeycomb froth that persists for $10-15 \mathrm{mins}$ indicates presence of saponins (Evans, 2009).

\section{Test for Flavonoids}

Shinoda Test: A portion of the extract was dissolved in $1-2 \mathrm{ml}$ of $50 \%$ methanol in the presence of heated metallic magnesium chips and a few drops of concentrated hydrochloric acid were added. Appearance of red color indicates the presence of flavonoids (Evan, 2009). 
BAJOPAS Volume 14 Number 1, June, 2021

Test for Alkaloids

Wagner's Test: Few drops of Wagner's reagent was added into a portion of the extract, white precipitate indicates the presence of alkaloids (Evans, 2009).

Test for Steroids and Triterpenes Liebermann-Burchard's test:

Equal volumes of acetic acid anhydride was added to the portion of the extract and mixed gently. Concentrated sulphuric acid $(1 \mathrm{ml})$ was added down the side of the test tube to form a lower layer. A colour change observed immediately and later indicates the presence of steroid and triterpenes. Red, pink or purple colour indicates the presence of triterpenes while blue or blue green indicates steroids (Evans, 2009).

\section{Test for Cardiac Glycosides}

Kella-killiani's test:

A portion of the extract was dissolved in $1 \mathrm{ml}$ of glacial acetic acid containing traces of ferric chloride solution. This was then transferred into a dry test tube and $1 \mathrm{ml}$ of concentrated sulphuric acid was added down the side of the test tube to form a lower layer at the bottom. Interphase for purple-brown ring was carefully observed, this indicates the presence of deoxy sugars and pale green colour in the upper acetic acid layer indicates the presence of cardiac glycosides (Evans, 2009).

\section{Test for Tannins}

Ferric chloride test:

Exactly 3-5 drops of ferric chloride solution was added to the portion of the extract. A greenish black precipitate indicates the presence of condensed tannins while hydrolysable tannins give a blue or brownish blue precipitates (Evans, 2009).

\section{Test for Anthraquinones}

Borntrager's test:

Exactly $5 \mathrm{ml}$ of chloroform was added to the portion of the extract in a dry test tube and shaken for at least 5 mins. This was filtered, and the filtrate shaken with equal volume of $10 \%$ ammonium solution, bright pink colour in the aqueous upper layer indicates the presence of free anthraquinones (Evans, 2009).

\section{Quantitative Determination of Phytochemical Contents of Anogeissus leiocarpus Stem \\ Determination of Alkaloids}

About $5 \mathrm{~g}$ of the sample weighed into a $250 \mathrm{ml}$ beaker and $200 \mathrm{ml}$ of $10 \%$ acetic acid in ethanol was added, covered and allowed to stand for 4hours. This was filtered and the extract was concentrated on a water bath to one quarter of the original volume. Concentrated ammonium hydroxide was added drop wise to the extract until the precipitation is completed. The whole solution was allowed to settle, and the precipitates were collected, washed with dilute ammonium hydroxide solution and then filtered. The residue was the alkaloids, which was then dried and weighed (Harborne, 1973).

\section{Determination of Flavonoids}

About $10 \mathrm{~g}$ of the plant sample was extracted repeatedly with $100 \mathrm{ml}$ of $80 \%$ aqueous methanol at room temperature. The whole solution was filtered through Whatman filter upper No. $42(125 \mathrm{~mm})$. The filtrate was later be transferred into a crucible and evaporated into dryness over a water bath and weighed to a constant weight (Bohm and Kocipal - Abyazan, 1994).

\section{Determination of Saponins}

The method of Obadoni and Ochuko (2001) was adopted. Sample $(10 \mathrm{~g})$ was transferred into a conical flask and $100 \mathrm{ml}$ of $20 \%$ aqueous ethanol was added. The sample was heated over a hot water bath for 4 hours with continuous stirring at about $55^{\circ} \mathrm{C}$. The mixture was filtered and the residue re-extracted with another $200 \mathrm{ml}, 20 \%$ ethanol. The combined extracts were reduced to $40 \mathrm{ml}$ over water bath at about $90^{\circ} \mathrm{C}$. The concentrate was transferred into a $250 \mathrm{ml}$ separatory funnel and $20 \mathrm{ml}$ of diethyl ether was added and shaken vigorously. The aqueous layer was recovered while the ether layer was discarded. The purification process was repeated and $60 \mathrm{ml}$ of $\mathrm{n}$ - butanol was added. The combined $n$-butanol extract was washed twice with $10 \mathrm{ml}$ of $5 \%$ aqueous sodium chloride. The remaining solution was heated in a water bath. After evaporation the samples were dried in the oven to a constant weight. The saponins content was calculated.

\section{Determination of Tannins}

About 500mg of the sample was weighed into a $50 \mathrm{ml}$ plastic bottle and $50 \mathrm{ml}$ of distilled water was added and shaken for 1hour on a mechanical shaker. This was filtered into a $50 \mathrm{ml}$ volumetric flask and made up to the mark. Then $5 \mathrm{ml}$ of the filtrate was pipetted out into a test tube and mixed with $2 \mathrm{ml}$ of $0.1 \mathrm{M} \mathrm{FeCl}_{3}$ in $0.1 \mathrm{M}$ $\mathrm{HCl}$ and $0.008 \mathrm{M}$ potassium ferro-cyanide. The absorbance was measure at $120 \mathrm{~nm}$ within 10mins (Van-Burden and Robinson, 1981).

\section{Determination of Total Phenols}

The fat free sample was boiled with $50 \mathrm{ml}$ of ether for 15 minutes. About $5 \mathrm{ml}$ of the extract was pipetted into a $50 \mathrm{ml}$ flask, and then $10 \mathrm{ml}$ of distilled water was added. About $2 \mathrm{ml}$ of ammonium hydroxide solution and $5 \mathrm{ml}$ of concentrated amyl alcohol were added. The sample was made up to mark and allowed to react for about 30 minutes for colour development. This was measured at $505 \mathrm{~nm}$. 
BAJOPAS Volume 14 Number 1, June, 2021

Antimicrobial Susceptibility Test

Preparation of Extract Concentration

This was carried out according to the method described by Srinivasan et al., (2009). Stock solution of the plant extracts were prepared by adding $0.5 \mathrm{~g}$ of crude plant extract in $1 \mathrm{ml}$ dimethyl sulphuroxide (DMSO). From each of the stock solutions, $500 \mathrm{mg} / \mathrm{ml}, 250 \mathrm{mg} / \mathrm{ml}$, $125 \mathrm{mg} / \mathrm{ml}$ and $62.5 \mathrm{mg} / \mathrm{ml}$ concentrations were prepared using Two-fold serial dilution method (Srinivasan et al., 2009).

\section{Standardization of bacterial Inoculum}

Using inoculum loop, over-night grown agar culture (bacteria) was transferred into a test tube containing normal saline until the turbidity of the suspension matched the turbidity of the 0.5 McFarland Standard as described by the National committee for clinical laboratory standard (NCCLS, 2008).

Susceptibility Test of Bacterial isolates to Different Concentrations of the Extracts

The antimicrobial activity of Anogeissus leiocarpus crude extract (Methanol) against Streptococcus mutans, Streptococcus salivarius, Staphylococcus aureus, Streptococcus pyogenes, sanguinis were evaluated using agar well diffusion method of susceptibility test (Srinivasan et. al., 2009). Mueller-Hinton agar plates was inoculated with $0.1 \mathrm{ml}$ of standardized inoculum of each bacterium and fungus respectively (in triplicates) using $0.1 \mathrm{ml}$ pipette and spread uniformly with sterile swab sticks. Three wells of $6 \mathrm{~mm}$ size were made with sterile cork borer (6 $\mathrm{mm}$ ) into the inoculated agar plates. Using micropipette, $0.1 \mathrm{ml}$ volume of the various concentrations; $\quad 500 \mathrm{mg} / \mathrm{ml}, \quad 250 \mathrm{mg} / \mathrm{ml}$, $125 \mathrm{mg} / \mathrm{ml}$ and $62.5 \mathrm{mg} / \mathrm{ml}$ of the crude extracts were dispensed into wells of inoculated plates. . DMSO was used as negative control. Commercially available standard antibiotic, ciprofloxacin and fluconazole were used as positive control parallel with the extracts. The prepared plates were then left at room temperature $\left(37^{\circ} \mathrm{C}\right)$ for 10 minutes, allowing the diffusion of the extracts into the incubation at 37 ${ }^{\circ} \mathrm{C}$ for $24 \mathrm{hrs}$ in an incubator. The diameter of inhibition zones (DIZ) were measured and expressed in $\mathrm{mm}$.

Determination of Minimum Inhibitory Concentration (MIC)

The method used was the tube dilution method (Adesokan et al., 2007). Thus, the plant extract was serially diluted from $500 \mathrm{mg} / \mathrm{ml}$ solution to obtain varying concentration. The concentrations were; $250 \mathrm{mg} / \mathrm{ml}, 125 \mathrm{mg} / \mathrm{ml}, 62.5 \mathrm{mg} / \mathrm{ml}$, and $31.25 \mathrm{mg} / \mathrm{ml}$. Doubling dilutions of the extract were incorporated in Muller Hinton broth (Oxoid, UK), and then inoculated with $0.1 \mathrm{ml}$ each of standardized suspension of the test organisms into the various test tube containing varying concentrations. Another set of test tubes containing only Mueller Hinton broth were used as negative control, and another test tube containing Mueller Hinton broth and test organisms were used as positive control. All the test tubes and controls were then incubated at $37{ }^{\circ} \mathrm{C}$ for $24 \mathrm{hrs}$. After incubation period, the presence or absence of growth on each tube was observed. A loop full from each tube was further sub cultured onto nutrient agar to confirm whether the bacterial growth was inhibited.

Determination of Minimum Bactericidal Concentration (MBC)

The MBC was determined by collecting $1 \mathrm{ml}$ of broth culture from the tubes used for the MIC determination and subculturing into fresh solid nutrient agar plates. The plates were incubated at $37{ }^{\circ} \mathrm{C}$ for $24 \mathrm{~h}$. The least concentration that did not show any growth after incubation was regarded as the MBC (Adesokan et al., 2007).

Acute toxicity studies of methanol extract of Anogeissus leiocarpus Stem

Lethal Dose $\left(\right.$ LD $\left._{50}\right)$ Determination

The method of Lorke (1983) was employed. Thus, the phase I involved the oral administration of three different doses of 10 , 100 and $1,000 \mathrm{mg} / \mathrm{kg}$ of the crude extract, to three different groups of three adult wister albino rats. In a fourth group, three adult male wister albino rats were administered with equivalent/volume of distilled water to serve as control. All the animals were orally administered with the extracts using a curved needle to which acatheter had been fixed. The animals were monitored closely every 30 minutes for the first 3 hours after administration of the crude extracts, and then hourly for the next 6hours for any adverse effects. Then the animals were left for 72 hours for further observation.

When no death occurred, the phase II was employed, only one animal was required in each group. Groups 1-4, animals were orally given $1,500,2,200,3250$ and $5,000 \mathrm{mg} / \mathrm{kg}$ dose levels of the crude extract. All the animals were left for observation as in stage one. 
BAJOPAS Volume 14 Number 1, June, 2021

RESULTS

The plant material was extracted with methanol to yield brown extract $(10.4 \mathrm{~g})$ (Table 1 ).

Table 1. Mass and Percentage Yield for the Extract of Anogeissus leiocarpus

$\begin{array}{cccc}\text { Extract } & \text { Mass }(\mathrm{g}) & \text { Percentage Yield (\%) } & \text { Extract Appearance } \\ \text { Methanol } & 10.4 & 20.8 & \text { Brown }\end{array}$

Flavonoid, steroid, triterpenes, alkaloids, tannins, carbohydrate, glycoside, phenols were detected in the extract while anthraquinones was absent (Table 2).

Table 2. Phytochemical screening of the whole plant of Anogeissusl eiocarpus

\begin{tabular}{lc}
\hline Phytochemical & Inference \\
\hline Alkaloid & + \\
Flavonoid & + \\
Saponins & + \\
Cardiac glycoside & + \\
Tannins & + \\
Steroid & + \\
Triterpenes & + \\
Phenol & + \\
Anthraquinones & - \\
Carbohydrate & + \\
\hline
\end{tabular}

Table 3 showed the phytochemical contents of Anogeissus leiocarpusin the methanol extract. highest content in the extract while the lowest The alkaloids $(412 \mathrm{mg} / \mathrm{g})$ was found to have the content was observed insaponins $(4.0 \mathrm{mg} / \mathrm{g})$.

Table 3. Quantitative Phytochemical screening of methanolic stem extract of Anogeissus leiocarpus

\begin{tabular}{ll}
\hline Metabolite & Quantity $(\mathrm{mg} / \mathrm{g})$ \\
\hline Alkaloids & $412 \pm 0.33$ \\
Flavonoids & $223 \pm 0.40$ \\
Saponins & $4.00 \pm 0.33$ \\
Tannins & $243.0 \pm 0.22$ \\
Phenols & $12.0 \pm 0.50$ \\
\hline
\end{tabular}

Antibacterial activity of methanol extract showed inhibition on all the tested organisms $S$. aureus (11-22 mm),Streptococcus mutans (08-14 mm), Streptococcus salivarius (10-16 $\mathrm{mm})$, Streptococcus pyogenes (11-16 mm),
Streptococcus sanguinis (10-16 mm)(Table 4). The MIC and MBC of the extract recorded respective values of $12.5 \mathrm{mg} / \mathrm{ml}$ and $25 \mathrm{mg} / \mathrm{ml}$ against all the tested clinical isolates.

Table 4. Antibacterial activity of methanol extract of Anogeissus/ eiocarpus stem

\begin{tabular}{lcccccccc}
\hline Clinical isolates & \multicolumn{9}{c}{ Concentration/Diameter zone of inhibition } & MIC & MBC \\
\cline { 2 - 6 } & 500 & 250 & 125 & 62.5 & Ampicillin & DMSO & & \\
S. aureus & 22 & 17 & 14 & 11 & 32 & 06 & 31.25 & 62.5 \\
S. pyogenes & 16 & 13 & 11 & 09 & 34 & 06 & 31.25 & 62.5 \\
S. mutans & 14 & 12 & 10 & 08 & 30 & 06 & 31.25 & 62.5 \\
S. salivarius & 16 & 14 & 12 & 10 & 32 & 06 & 31.25 & 62.5 \\
S. sanguinis & 16 & 14 & 12 & 10 & 33 & 06 & 31.25 & 62.5 \\
\hline
\end{tabular}

Toxicity study indicate no death recorded in the first phase of the investigated rats. In the second phase, doses of 1500, 2250, 3250 and $5000 \mathrm{mg} / \mathrm{kg}$ were used and no death was also recorded. The oral median lethal dose $\left(L_{50}\right)$ for the methanol stem extract of Anogeissus leiocarpus was therefore estimated to be greater than $5000 \mathrm{mg} / \mathrm{kg}$ and no sign of behavioural changes were also observed (Table 5). 
BAJOPAS Volume 14 Number 1, June, 2021

Table 5. Acute toxicity studies of methanolic stem extract of Anogeissus leiocarpus

\begin{tabular}{|c|c|c|c|c|}
\hline Treatment & Group & $\begin{array}{c}\text { Number of } \\
\text { Animals }\end{array}$ & Dose $(\mathrm{mg} / \mathrm{kg})$ & $\begin{array}{c}\text { Mortality recorded } \\
\text { after } 24 \mathrm{hrs}\end{array}$ \\
\hline \multirow[t]{2}{*}{ Phase I } & I & 3 & 10 & $0 / 3$ \\
\hline & $\begin{array}{l}\text { II } \\
\text { III }\end{array}$ & $\begin{array}{l}3 \\
3\end{array}$ & $\begin{array}{c}100 \\
1000\end{array}$ & $\begin{array}{l}0 / 3 \\
0 / 3\end{array}$ \\
\hline \multirow[t]{4}{*}{ Phase II } & I & 1 & 1500 & $0 / 1$ \\
\hline & II & 1 & 2250 & $0 / 1$ \\
\hline & III & 1 & 3250 & $0 / 1$ \\
\hline & IV & 1 & 5000 & $0 / 1$ \\
\hline
\end{tabular}

\section{DISCUSSION}

The phytochemical profile of the methanol extract from the stem of Anogeissus leiocarpus showed the presence of flavonoids, saponins, tannins and triterpenes (Table 2). These chemical compounds have been associated with antimicrobial activities (Moola, 2014). Alkaloids are well known for their wide range of pharmacological activities so this finding confirms the potential of Anogeissus/ eiocarpus as potential antimicrobial agents (Moola, 2014). Anogeissus leiocarpus displayed a low saponins content. The presence of saponins in the extract is of importance because saponins are known to be immune boosters (Moola, 2014). Results of the phytochemical screening are in accordance with the popular use of the Anogeissus leiocarpus as chewing sticks since the results show the presence of various secondary metabolites that are associated with various pharmacological effects. The presence of saponins in Anogeissus leiocarpus stem supports its traditional use for procuring abortion since saponins are linked to the sex hormone oxytocin involved in controlling the onset of labour (Njoku and Akumefula, 2007). The presence of tannins suggest the growth inhibitory effect of these plant extracts on bacteria. A study conducted by Sharallet al., (2013) reported the presence of fatty acids and terpenes responsible for bactericidal activity. Hamid et al. (2011) also reported that phenolics, flavonoids, saponins and phorbol esters as antimicrobial compounds in Anogeissusl eiocarpus. Phytochemicals present in the stem extract was high but moderate antimicrobial activity was observed, probably due to the fact that different phytochemical compounds exert their antibacterial effects differently from one another. A similar result was also reported by Willey et al. (2008) that the presence of some secondary metabolites in the root extract of $\mathrm{J}$. curcus inhibit microorganisms isolated from sexually transmitted infections. Henrie et al. (2009) reported that J. curcus root and Anogeissus leiocarpus stem extract disrupts bacterial cell membrane by increasing membrane permeability and causing leakage of bacterial contents like nucleic acid and amino acids. Agarwal et al.(2012) also states that the presence of metabolic toxins or broad spectrum antimicrobial compounds in Anogeissus leiocarpus stem acts against most Gram positive and some Gram negative bacteria especially in solvents methanol, ethyl acetate and cold aqueous. In the same vein, Igbinosa et al. (2011) reported that the activities of J. curcus and Anogeissus leiocarpus stem to both Gram positive and negative microorganism can be attributed to the presence of phenolic compounds which showed to be powerful antioxidants and free radical scavengers, and those compounds are able to induce reactions of electron transfer which reacts with nitrogen compound in microbial cell like nucleic acid and proteins, this helps as a strong barrier against bacterial infection.

The result of the antimicrobial susceptibility test showed that the extract had antibacterial activity against the characterized microorganisms isolated from the mouth. This was reflected in the varying zones of inhibition of the individual extracts on the oral pathogens in vitro with mean inhibition diameters that ranged from $S$. aureus (11-22 mm), Streptococcus mutans (08$14 \mathrm{~mm})$, Streptococcus salivarius $(10-16 \mathrm{~mm})$, Streptococcus pyogenes (11-16 mm)and Streptococcus sanguinis $(10-16 \mathrm{~mm})$. This is an indication that the extract possess substances that can inhibit the growth of microorganisms' particularly oral pathogens. Although the phytochemical screen test showed that the plant part from Anogeissus leiocarpus contain polyphenols, saponins and tannins which are potentially good antimicrobial agents (Duru and Onyedineke, 2010). Mbanga et al., (2013) reported that the aqueous extracts from $D$. lycioides and Anogeissus leiocarpus were active against multidrug sensitive and multidrug resistant $S$. mutans isolates.

The MIC and MBC assay procedures are frequently used to evaluate some diverse agents such as antibiotics, antiseptics, disinfectants and chemotherapeutic agents (Andrews, 2001). In this study, the MIC and MBC values of all the tested clinical isolates with methanolic extract of 
BAJOPAS Volume 14 Number 1, June, 2021

Anogeissus leiocarpus indicates significant bactericidal activities. This implies the strong efficacy of the extract as stated by Arekemase (2011) that the constituents of the stem of Anogeissus leiocarpus contains phenols, flavonoids and some secondary metabolites that are very useful in antimicrobial activity. This moderate MIC exhibited by Anogeissus leiocarpus is of great significance because it suggests that this extract can be used in the prevention of dental caries. It also suggests that using Anogeissus leiocarpus stem as teeth cleaning agents can kill oral pathogens. It can also indicate that chewing of the stem of Anogeissusleiocarpus can be an effective teethcleaning agent and thus can be an alternative to conventional toothbrush and toothpaste method since it is cheaper. Inhibition of bacterial adhesion may be associated with the modification of the receptors on the cell surface of the bacteria (Rahim and Khan, 2006). This is an important factor to consider because it means that using these plants as chewing sticks can reduce the adhesion of pathogenic oral microorganisms to the teeth surface and thus limit plaque formation.

In order to determine the safety margin of drugs and plant products for human use, toxicological evaluation was carried out in experimental animals using Lorke's method to predict toxicity and to provide guidelines for selecting a "safe" dose in animals and also used to estimate the therapeutic index $\left(\mathrm{LD}_{50}\right)$ of drugs (Rang et al., 2012). In this study, median lethal dose $\left(L_{50}\right)$ of the methanol extract of the Anogeissus leiocarpus stem was carried out orally in rats. The $\mathrm{LD}_{50}$ was found to be greater than 5000

\section{REFERENCES}

Abubakar, U.S., K.M. Yusuf, G.T., Abdu, S.R. Saidu, G.A., Jamila, A. Fatima (2017). Ethnopharmacological Survey of Medicinal Plants used for the Management of Pediatric Ailments in Kano State, Nigeria. Research Journal of Pharmacognosy. 4(3): 29-39.

Aderinokun, G.A., Lawoyin, J.O. and Onyeaso, C.O. (1999). Effects of two common Nigerian chewing sticks on gingival health and oral hygiene. OdontoStomatologie Tropicale, 87, 13-18.

Adesokan, A. A., Akanji, M. A. and Yakubu, M. T. (2007). Antibacterial potentials of aqueous extract of Enantiachlorantha stem bark. African Journal of Biotechnology, 6(22).

Agarwal, T., Rachana, S., Rinki, R. and Neha, A. (2012).Comparative analysis of antibacterial activity of Jatropha $\mathrm{mg} / \mathrm{kg}$ when administered orally in rats (Table 5 ) and all the animals remain alive and did not manifest any significant visible signs of toxicity at these doses. These studies showed the extract of Anogeissus leiocarpus stem are practically non-toxic when administered using the oral route (Table 6 ). This is based on the toxicity classification which states that substances with $\mathrm{LD}_{50}$ values of 5000 to 15,000 $\mathrm{mg} / \mathrm{kg}$ body weight are practically non-toxic (Loomis and Hayes, 1996).

\section{CONCLUSIONS}

The standardization for the Anogeissus leiocarpus stem will be useful for the compilation of suitable pharmacopoeia parameters and also serve as a basis for proper identification and safety usage of Anogeissus leiocarpus stem. Anogeissus leiocarpus stem possess secondary metabolites which include alkaloids, tannins, flavonoids, cardiac glycosides and saponins. Antibacterial activity showed that the plant contain biologically active compounds which prevent the growth and/or attachment of oral pathogens $S$. mutans, $S$. aureus, $S$. salivarius, $S$. pyogenes and $S$. sanguinis. The study confirms the use of this plant as chewing stick in removing plaque not only mechanically but also with antibacterial and anti-adhesion effects. The Acute toxicity $\left(L D_{50}\right)$ of the methanolic extract of Anogeissus leiocarpus stem was found to be greater than $5000 \mathrm{mg} / \mathrm{kg}$ and is considered safe for use. Nonetheless, further studies are encouraged to evaluate toxicity at much higher doses.

\section{Conflict of interest}

None to declare.

$$
\begin{aligned}
& \text { Curcasfruit parts. J ournal of } \\
& \text { Pharmaceutical and biomedical } \\
& \text { sciences,2230(7885):12-15. }
\end{aligned}
$$

Ahmad, A. H. (2014). Review on Anogeissus eiocarpus. A Potent African Traditional Drug. International Journal of Research in Pharmacy and Chemistry. 4(3): 496500.

Akanbi, O.M (2012). The Antiplasmodial Activity of Anogeissus leiocarpus and its effect on Oxidative Stress and Lipid Profile in Mice Infected with Plasmodium bergheii. Parasitology Research. 110(1):219-226.

Andrews, A.M. (2001). Determination of minimum inhibitory concentrations. Journal of Antimicrobial chemotheraphy, 48(1):5-16.

Arekemase, M.O., Kayode, R.M.O. and Ajiboye, A.E. (2011). Antimicrobial activity and phytochemical analysis of Jatropha curcas plant against some selected 
BAJOPAS Volume 14 Number 1, June, 2021 microorganisms. International Journal of Biology, 3(3):52-59.

Batawila, K., Kokou, K., Koumagolo, K., Gbessor, M., de Foucault, B., Bouchet, P. and Akpagana, K. (2005). Antifungal Activities of Five Combretaceae Used in Togolese Traditional Medicine. Fitoterapí. 76(2): 264-268.

Bohm, B.A. and Kocipal - Abyazan, R. (1994). Flavonoids and condensed tannins from leaves of Hawaiian vaccinium aticulation and $V$. cerlycicium. Journal of Pacific Science. 48: 458 - 463.

Cai, L., Wei, G., van der Bijl, P., Wu, C.D. (2000). Namibian chewing stick, Diospyros/ycioides, contains antibacterial compounds against oral pathogens. Journal of Agricultural and Food Chemistry, 48, 909-914.

Cheesbrough, M. (2010). Biochemical tests to identify bacteria: District Laboratory Practice in tropical countries. Part 2, update edition Cambridge University Press. pp 62-105

Duru, C.M. and Onyedineke, N.E. (2010). In vitro study on the antimicrobial activity and phytochemical analysis of ethanolic extracts of the mesocar of Voacangaafricana. American Journal of Plant Physiology, 5(4), 163-169.

Elegami, A.A (2002). Antimicrobial Activity of some Species of the family Combretaceae. Phytother Res. 16(6):555-61.

Evans, W.C. (2009). Trease and Evans Pharmacognosy. 16th edition. Elselviers Ltd., UK, Pp.560-562, 568-570.

Hamid, A.A., Aiyelaagbe, O.O. and Usman, L.A. (2011). Essential oils: Its medicinal and pharmacological uses. International Journal of Current Research, 3(2):086098.

Harborne, Z. B. (1973). Phytochemical methods: A guide to modern techniques of plant analysis, 3rd edn. Chapman and Hall Press, London. Pp. 13, 53, 53 195, 283.

Henrie, E.H., Zaitan, H. and Suhaila, M. (2009). Bacterial Membrane disruption in food pathogens by Psidiumguajava extracts. International Food Journal, 16:297-311.

Igbinosa, O.O., Igbinosa, I.H. and Vincent, N.C. (2011). Polyphenolic contents and antioxidant potential of stem bark extracs from Jatropha curcas (Linn). International Journal of Molecular Sciences, 12;(5):2958-2971.

Loomis, T.A. and Hayes, A.W. (1996). Loomis Essentials of Toxicology. (4th ed.).
California, U.SA: Academic Press; P208245.

Lorke D. (1983). A New Approach to Practical Acute Toxicity Testing. Arch Toxicol; 5: 275-287.

Mbanga, J., Ncube, M., \& Magumura, A. (2013). Antimicrobial activity of Euclea undulate, Eucleadivinorum and Diospyros/ycioides extracts on multidrug resistant Streptococcus mutans. Journal of Medicinal Plants Research, $7(37), 2741-2746$.

Moola, M.N. (2014). Phytochemical and Antibacterial analysis of Indigenous Chewing sticks Diospyroslycoides and Eucleadivinorum. M.sc Chemistry Research Dissertation (Unpublished).Department of Chemistry and Biochemistry, University of Namibia) Pp: 4-8, 88-100.

More, G., Tshikalangea, T.E., Lall, N., Botha, F., Meyer, J.J.M. (2008). Antimicrobial activity of medicinal plants against oral microorganisms. Journal of Ethnopharmacology, 119(3), 473-477.

Mukhtar, Y., Abdu, K. \& Maigari, A. K.(2017). Efficacy of Anogeissusleiocarpus (DC.) as Potential Therapeutic Agent against Trypanosomiasis Diseases: A Review. International Journal of Health and Pharmaceutical Research. 3 (3): 1-9. www.iiardpub.org

National Committee for Clinical Laboratory Standards (2008).Performance Standards for Antimicrobial Susceptibility Testing; Ninth Informational Supplement. NCCLS document M100-S9. National Committee for Clinical Laboratory Standards, Wayne, PA

National Committee for Clinical Laboratory Standards NCCLS (2000).Methods for dilution antimicrobial susceptibility tests for bacteria that grow aerobically: approved standards- fifth edition. NCCLS document M7-A5. NCCLS. 2000: Wayne, PA, USA

Njoku, P.C., \& Akumefula, M.I. (2007). Phytochemical and nutrient evaluation of Spondiasmombin leaves. Pakistan Journal of Nutrition, 6(6), 613-615.

Obadoni, B.O. and Ochuko, P.O. (2001). Phytochemical studies and comparative efficacy of the crude extracts of some Homostatic plants in Edo and Delta states of Nigeria". Journal of Pure and Applied Sciences, 8:203 -208.

Odongo, C.O., Musisi, N.L., Waako, P. and Obua, C. (2011). Chewing-stick practices using plants with anti-streptococcal activity in 
BAJOPAS Volume 14 Number 1, June, 2021

a Ugandan rural community. Frontiers in Pharmacology,

2(13).doi:10.3389/fphar.2011.00013.

Palombo E.A. (2009). Traditional medicinal plant extracts and natural products with activity against oral bacteria: Potential application in the prevention and treatment of oral diseases. Hindawi Publishing Corporation. Vol 2011

Rang, H.P., Dale, J.M., Ritter, R.J., Flower, G. and Henderson, G. (2012). Rang and Dale's pharmacology. (7th ed.). London: Churchill Livingstone; 377 p.

Sharall, V., Verma M., Sharma, S. and Malik, A. (2013). Determination of Phytocomponents of Jatropha curcas root by GC-MS Analysis and their Termcidal activity.

Shuaibu, M.N.(2008). Trypanocidal activity of extracts and compounds from the stem bark of Anogeissusleiocarpus and Terminalia avicennoides. Parasitology Research. 102(4): 697-703.

Srinivasan, L., Sasaki, Y., Calado, D.P., Zhang, B., Paik, J.H., DePinho, R.A., Kutok, J.L., Kearney, J.F., Otipoby, K.L. and Rajewsky, K. (2009). PI3 kinase signals BCR-dependent mature B cell survival. Cell, 139:573-586.

Sylvester, N.M. (2016). Phytochemical and Antivenom activity of Albiziachivelieri stem bark on Najanigricollis Broadley Envenomated Mice. M.sc Research Dissertation (Unpublished).Department of Pharmacognosy and Drug Development Library. Ahmadu Bello University, Zaria. Pp: 47-48.

Taiwo, O., Xu, H.X. and Lee, S.F.(1999). Antibacterial Activities of Extracts from Nigerian chewing sticks. Phytother Res. 13(8):675-9.

Van - Burden, T. P; and Robinson, W.C. (1981). Formation of complexes between protein and tannin acid. Journal of Agricultural Food Chemistry. 17:772 - 777.

Victor, B.Y.A. and Grace A.(2013). Phytochemical Studies, In-vitro Antibacterial Activities and Antioxidant Properties of the Methanolic and Ethyl Acetate Extracts of the Leaves of Anogeissusleiocarpus. International Journal of Biochemistry Research and Review. 3(2):173-145.

Victor, Y.A.(2013). In-Vitro Assessment of Antioxidant and Antimicrobial Activities of Methanol Extracts of Six Wound Healing Medicinal Plants. Journal of Natural Science Research. 3(1): 74-82.

Willey, J.M., Sherwood, L.M. and Woolverton, C.J. (2008). Prescott, Harley and Kleins Microbiology, 7th Edition. McGraw Hill, New York, NY 10020.1088pp. 